Historic, Archive Document

Do not assume content reflects current scientific knowledge, policies, or practices. 



\begin{abstract}
Eastern redcedar, Scots pine, and ponderosa pine were planted at 4-, 6- and 8-foot (1.2, 1.8 and $2.4 \mathrm{~m})$ spacings in five combinations in singlerow field windbreaks in northcentral Nebraska. Trees of all species grew significantly taller at the 4-foot spacing, but pine at that spacing will require thinning to maintain vigorous growth. Rows containing all Scots pine, all eastern redcedar, or combinations of Scots pine and eastern redcedar were tallest. Order of species desirability is eastern redcedar, Scots pine, and ponderosa pine. Most desirable spacings in each species combination and anticipated follow-up silvicultural recommendations are given. Unfenced single-row field windbreaks are damaged by livestock, and effects will be accumulative.
\end{abstract}


Conifers For Single-Row Field Windbreaks

David F. Van Haverbeke

Research Forester

Rocky Mountain Forest and Range Experiment Station' 


\section{Contents}

\section{Page}

Introduction $\ldots \ldots \ldots \ldots \ldots \ldots \ldots \ldots \ldots \ldots \ldots \ldots \ldots$

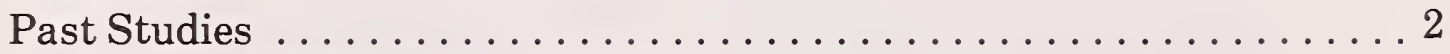

Study Areas and Design ........................ 2

Site Preparation and Planting . . . . . . . . . . . . . . . . 3

Maintenance and Measurements ..................... 3

Results.............................. 4

Fertilization ............................ 4

Seedling Survival and Replacement ................ 4

Spacing. . . . . . . . . . . . . . . . . . . . . . . . 4

Species Combinations (Height) . . . . . . . . . . . . . . 4

Discussion and Interpretation . . . . . . . . . . . . . . 5

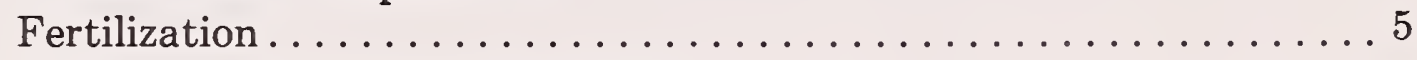

Seedling Survival and Replacement ................ 5

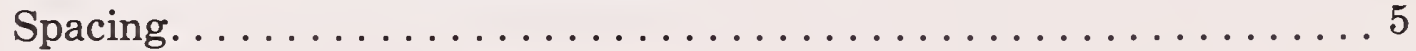

Species Combinations (Height) .................. 5

Species Combinations (Density) ................. 5

Livestock Damage. ....................... 8

Literature Cited. . . . . . . . . . . . . . . . . . . . . 9 


\title{
Conifers for Single-Row Field Windbreaks
}

\author{
David F. Van Haverbeke
}

\section{Highlights}

1. Spacings, species combinations, and silvicultural treatments leading to maximum early and sustained effectiveness appear to be:

a. Ponderosa pine spaced at 4 feet and thinned to 8 feet after 10 years.

b. Ponderosa pine and eastern redcedar planted alternately in pairs at 6 feet, and thinned to alternate 12 -foot interval after 10 years.

c. Scots pine planted at 6 feet and thinned to an alternate 12 -foot interval after 15 years.

d. Scots pine and eastern redcedar planted alternately at 8 feet and left unthinned.

e. Eastern redcedar planted at 4 feet and left unthinned, or thinned to 8-foot interval at age 10 , or planted at 6 feet and left unthinned.

2. Trees grow significantly taller, and become satisfactory windbarriers sooner, at 4 -foot spac- ings than at 6- or 8-foot spacings. Pine will require thinning at the 4 -foot spacing to maintain effectiveness.

3 . The order of species desirability for windbreaks is eastern redcedar, Scots pine, and ponderosa pine.

4. Tree rows containing ponderosa pine only will be significantly shorter than rows containing combinations of ponderosa pine and eastern redcedar. The latter combination will be significantly shorter than rows containing Scots pine and eastern redcedar, all eastern redcedar, or all Scots pine.

5. Unfenced windbreaks will be damaged by livestock turned into the fields in the fall to glean unharvested grain; this damage will increase each year.

6. Fertilization of single-row conifer windbreaks, planted on previously and currently fertilized soils, does not appear to be necessary during the establishment period.

\section{Introduction}

Field windbreak design in the central and northern Great Plains has evolved during the past several decades from the multiple-row structures planted in the 1930's and 1940's to much narrower windbreaks - often single rows. High land values, increased taxation, improved crop varieties and cultural practices, irrigation, and a diminishing dependence on trees to provide fuel and farm products have stimulated this trend. The concept of single-row windbreaks is not entirely new, however; witness the many miles of single-row Osage-orange (Malcura pomifera) hedgerows established in Nebraska, Kansas, and Oklahoma in the early 1900's, and the single-row plantings of Siberian peashrub (Caragana arborescens) in Canada during the 1950's and 1960's.

There is also an increasing trend to use mostly conifers in single-row windbreaks. Long life, adaptability to a wide range of site conditions, year-round protection, wildlife habitat, and comparative freedom from rodent, insect, disease and livestock damage, make the conifers - particularly the junipers - a sound foundation upon which to base Plains windbreak planting. Many windbreaks consist of eastern redcedar (Juniperus virginiana), pine, or combinations of a conifer and a broadleafed species. Throughout the central and northern Great Plains, especially on sandy soils subject to wind erosion, these windbreaks are oriented in an east-west direction to intercept northerly winter and southerly summer winds, and are spaced at parallel intervals of 1530 rods $(75$ to $150 \mathrm{~m}$ ) across the fields. Along with strip-cropping, minimum and stubble-mulch tillage, they are intended to provide year-round protection to fields and crops.

With no specific information on species performance, spacing, and fertilization for single-row conifer windbreaks, our objectives were to determine the effects of several within-row spacings on growth of three conifer species in a variety of combinations. The influence of fertilizer on the growth and development of single-row windbreak trees was also desired. Information gained will assist action agencies in formulating planting guidelines for single-row windbreaks. 


\section{Past Studies}

A number of Plains foresters, and others (Ferrell 1957, Worthington 1960, Smith 1961, Zaylskie and Worthington 1962, Stoeckeler 1963 and Woodruff, Fryrear and Lyles 1963) have advocated single-row field windbreaks. Their reasons for preferring single-row over multiplerow windbreaks are: fewer acres out of cultivation, ease of maintenance during and after establishment, increased vigor of trees, fewer trees needed to protect same amount of land, improved wildlife habitat over a larger area, and improved snow distribution.

Others cautioned against dependence upon a single row of trees to provide effective protection over a long period (Read 1964, Van Eimern et al. 1964, Caborn 1965, Sturrock 1975 and Podkopaev 1975). Their arguments against singlerow windbreaks were: lack of flexibility in management, gaps created by missing trees, and changes in density when lower branches die. They recommended relatively narrow belts of trees, 2 to 5 rows wide, to overcome the above problems and still not occupy excessive amounts of cropland. King (1970) and Sturrock (1972) suggested that a single row of a dominant species, complemented with one or more filling rows of shrubs or slow-growing trees, is aerodynamically efficient; and Eaton (1971) believed that such belts appear capable of maintaining leaf cover to ground level for long periods. Nevertheless, the use of singlerow windbreaks is increasing in the north-central United States and Canada (Dickerson and Woodruff 1969, Woodruff et al. 1976).

Greb and Black (1961) demonstrated that conifers cause very little "sapping" of soil moisture from adjacent cropland until 10 or 15 years after planting; whereas broadleafed trees cause serious loss of soil moisture out to 50 feet $(15 \mathrm{~m})$ within 5 to 8 years. Ponderosa pine (Pinus ponderosa var. scopulorum) has been widely planted as a windbreak species. This rapidly growing native of the Plains withstands drought (George 1953a), but is susceptible to attack by the pine tip moth (Rhyacionia bushnelli). Hansen (1930) and George (1953a, b) found that Scots pine (Pinus sylvestris) grows fairly rapidly but tends to become "open" in habit when mature, and should be planted on more favorable moisture sites.

Spacing of trees in windbreaks on the Plains has long been studied but little quantitative data are available concerning spacing in single-row plantings. Narrow initial spacings in multiplerow plantings result in early crown closure and the elimination of the need for cultivation at an early age (Yeager 1921, Bates 1944, Ware 1936, Ross 1939), but require thinning later (Deters and Schmitz 1936, Emerson 1940, and Bates 1944). Wide initial spacings make for easier cultivation, less competition for space and soil moisture (Isaac 1941, Rockwell 1943) and higher survival, but result in slightly less height growth (Randel 1959) and failure to produce a closed canopy (Cram and Morgan 1961).

Nagle and Steffen (1953) reported that spacing is not a factor until the trees begin to compete for moisture and light. After competition begins, spacing influences height growth and form, both which directly influence the effectiveness of the windbreak. Siddoway (1970) concluded that wide spacings between trees in single-row plantings result in better survival and improved snow distribution. Maintenance of optimum growing space, either by wide spacing at planting time or by later thinning, results in the most satisfactory growth (Nagle and Steffen 1953).

Spacings of less than $40 \mathrm{ft}^{2}\left(3.6 \mathrm{~m}^{2}\right)$ per tree of growing space have usually been considered too close for best development in multiple-row windbreaks. George $(1936,1948)$ concluded that spacing becomes an important factor after 10 years in the growth of conifers and should be based on the growth habits of the species planted.

Fertilization of windbreak trees is a relatively little researched phase of Plains forestry. Zaylskie (1962) believed that windbreak trees do not need as much fertilization as shade trees. Windbreaks are rarely, if ever, raked or burned to rid them of nutrient-providing leaves and other decaying vegetation as are most lawn plantings. Also, field windbreaks are usually established in soils with a history of past and continuing crop fertilization.

Bagley (1962) applied nitrogen, phosphorous, and potassium to the soil 10 inches beneath windbreak seedlings at planting time and reported no significant differences in survival and initial growth. He concluded that other factors, particularly soil moisture availability, were more important to the successful establishment of windbreak trees. He believed, however, that after the trees were established, growth responses could be expected from the use of commercial fertilizers if soil or foliage analysis indicated low nutrient availability.

\section{Study Areas and Design}

In 1964, Soil Conservation Service personnel located a suitable study site in Antelope County, north-central Nebraska, and secured the coopera- 
tion of the private landowners. ${ }^{2}$ The site was a gently rolling, upland, 110-acre (44 ha) field of deep loamy fine sand. Permanent water table was deeper than 5 feet $(1.5 \mathrm{~m})$ and annual rainfall in the area is about 24 inches $(610 \mathrm{~mm})$. The field had been cropped continually to rye.

The windbreak designs were planned cooperatively by USDA Forest Service, Soil Conservation Service personnel and Mr. Allemang to serve as a permanent windbreak system. Five parallel, single-row windbreak locations, each 2,600 feet $(795 \mathrm{~m})$ long and about 25 rods $(126 \mathrm{~m})$ apart, were staked out in an east-west direction (fig. 1). Rows were divided into three replications each 940 feet $(287 \mathrm{~m})$ long. Replications were subdivided into three spacing plots $(4,6$ and $8 \mathrm{ft}),(1.2$, 1.8 and $2.4 \mathrm{~m}$ ) each 280 feet $(85 \mathrm{~m})$ long. Spacing plots were further divided into a fertilized and nonfertilized subplot, each 140 feet $(43 \mathrm{~m})$ long.

One of five species combinations was assigned for planting in each row (fig. 1): all ponderosa pine, ponderosa pine and eastern redcedar, all Scots pine, Scots pine and eastern redcedar, and all eastern redcedar. In the rows of mixed species, pines and junipers were planted alternately at the 4 -foot $(1.2 \mathrm{~m})$ spacing and alternately in pairs at the 6 - and 8-foot (1.8 and $2.4 \mathrm{~m}$ ) spacings. Spacing and fertilizer treatments were assigned rar-

${ }^{2} \mathrm{Mr}$. and Mrs. William Allemang, Rural Route \#1, Clearwater, Neb. 68726. Mr. Allemang was recipient of an annual Goodyear Tire and Rubber Co. Outstanding Conservationist Award in 1965 for his past and continuing cooperation with the Antelope County Soil and Water Conservation District and for his interest in establishing this study. domly; but species rows were structured for uniformity, esthetic, and demonstration purposes. A completely randomized design was not desirable on private land.

\section{Site Preparation and Planting}

A soil sample (0-12 in) ( $300 \mathrm{~mm}$ ) was taken from the middle of each subplot to determine fertilizer needs. Commercial lime was surface applied to each fertilizer subplot at the rate of $2 \frac{1}{2}$ tons per acre $(0.4 \mathrm{ha})$ in a 10 -foot $(3 \mathrm{~m})$-wide strip and disked into the soil before planting.

Large and medium grades of $2+1$ seedlings of eastern redcedar, ponderosa pine and Scots pine were machine planted into their respective rows by the Soil and Water Conservation District planting crew in the spring of 1964. Eastern redcedar and ponderosa pine seed originated from north-central Nebraska and Scots pine seed originated from central Europe.

A commercial fertilizer (8-24-8), with sulfur (10) and zinc (2), was applied in a double band 8 inches $(20 \mathrm{~cm})$ deep and 12 inches $(30 \mathrm{~cm})$ from both sides of the seedling rows in the fertilizer plots at the rate of $2 \frac{1 / 2}{2}$ tons per acre $(0.4 \mathrm{ha})$. This treatment was applied only once - immediately following planting.

\section{Maintenance and Measurements}

Simazine $80 \mathrm{~W}$, at the rate of 3 pounds per acre (0.4 ha) active ingredient, was applied after planting and at the beginning of the next four growing seasons in a 36 -inch $(91 \mathrm{~cm})$ band over the seed-

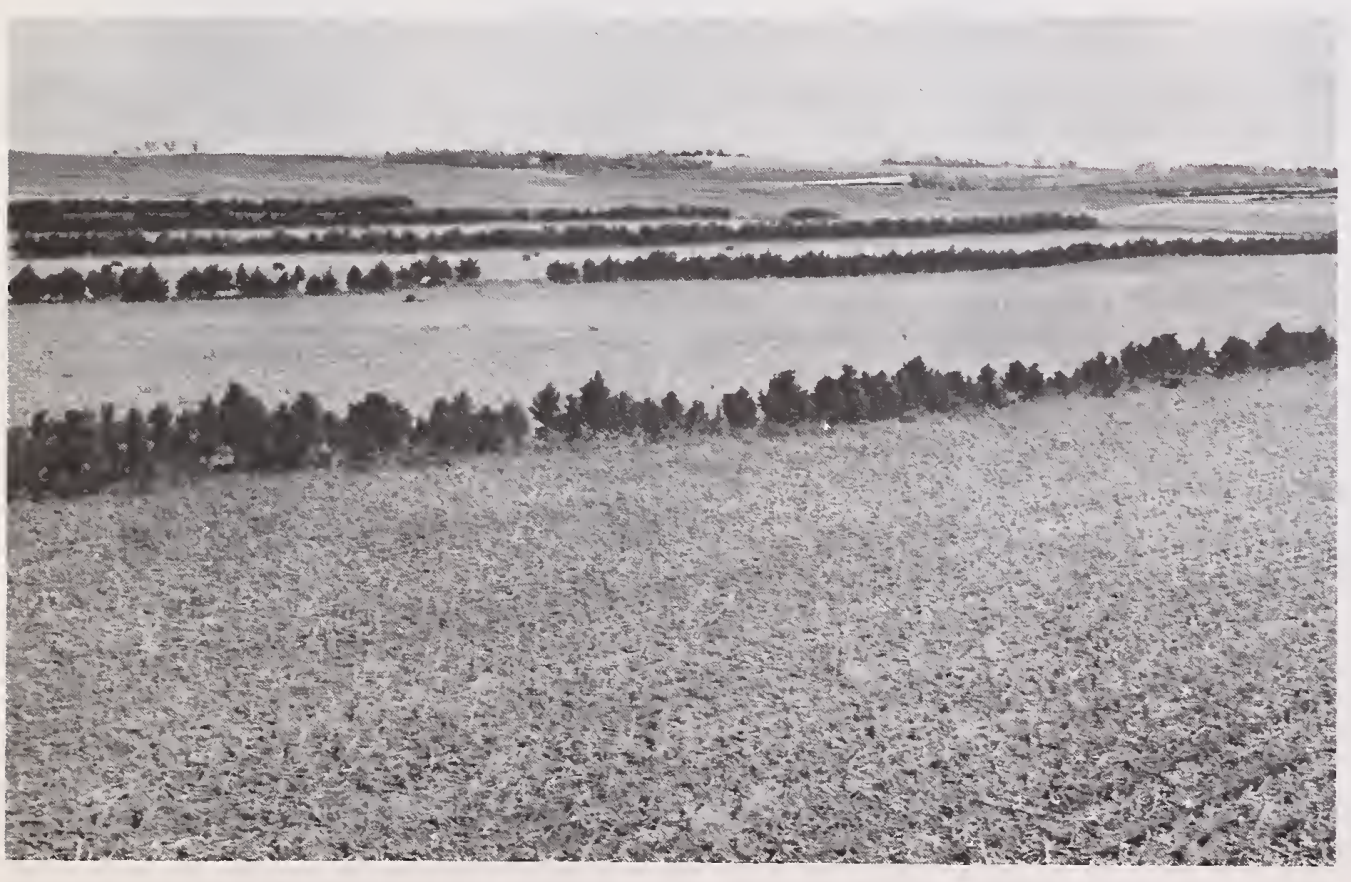

Figure 1.-Five single-row wind. breaks were established on a 110 . acre ( $44 \mathrm{ha}$ ) gently rolling field of deep loamy fine sand in north-cen. tral Nebraska to test spacing, conifer species combinations, and fertilization. 
ling rows by the Soil and Water Conservation District spraying crew to control weed growth within the rows. Weeds and grasses that grew alongside seedling rows were mowed twice each summer for 5 years. Dead seedlings were replaced during the first 3 years of the experiment.

Tree heights were measured and survival was recorded annually for 5 years; then biennially through 7 years. Photographs recorded crown development, vigor and density.

\section{Results}

\section{Fertilization}

Fertilizers had no significant influence on survival or growth of the trees.

\section{Seedling Survival and Replacement}

Survival (including replants) of conifer trees at the end of twelve growing seasons averaged $97 \%$ for all spacing and species combinations. Percentages averaged 99 in the ponderosa pine row, 95 in the ponderosa pine-eastern redcedar row, 98 in the Scots-eastern redcedar row, 99 in the eastern redcedar row and 96 in the Scots pine row. Only $8 \%$ of the seedlings required replacement during the study period.

\section{Spacing}

Trees spaced at 4 feet $(1.2 \mathrm{~m})$ grew significantly taller in 12 years than did trees at either 6 or 8 feet (fig. 2). Also, trees were consistently taller, but not significantly so at the 6-foot spacing than at the 8-foot spacing in all rows except those rows containing ponderosa pine.

\section{Species Combinations (Height)}

Average heights of trees, without regard to spacing, fertilizers and replications, were 8.9 feet $(2.7 \mathrm{~m})$ for ponderosa pine, 10.8 feet $(3.3 \mathrm{~m})$ for

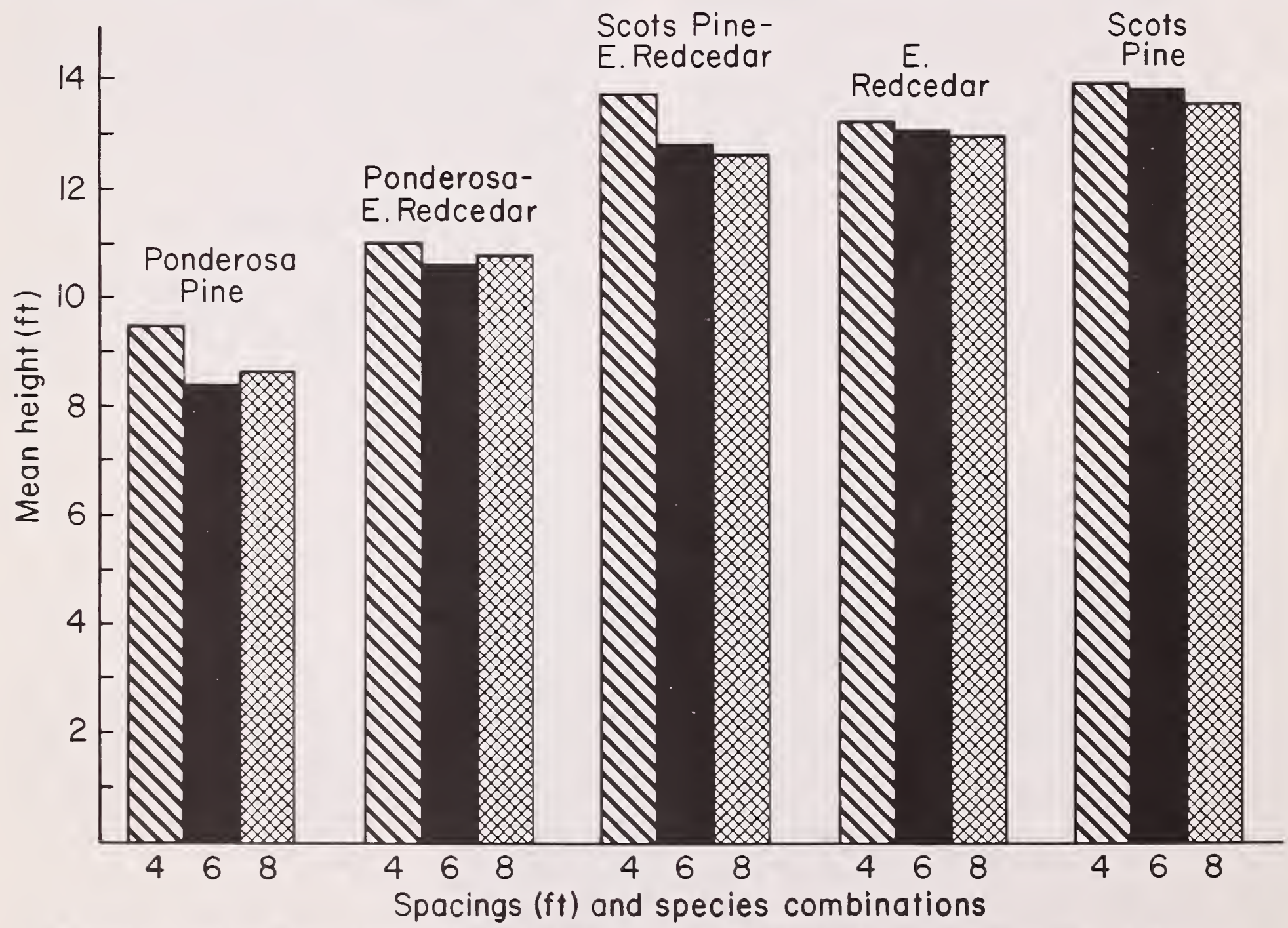

Figure 2. - Trees were significantly taller at a spacing of 4 feet in all species combination rows at the end of 12 years, and were consistently taller at the 6-foot spacing than at the 8-foot spacing except for rows containing ponderosa pine. Scots pine trees averaged 13.9 feet, eastern redcedar 13.2 feet, and ponderosa pine 8.9 feet in height. 
ponderosa pine-eastern redcedar, 13.1 feet $(4.0 \mathrm{~m})$ for Scots pine-eastern redcedar, 13.2 feet $(4.0 \mathrm{~m})$ for eastern redcedar, and 13.9 feet $(4.2 \mathrm{~m})$ for Scots pine. Tree rows containing only ponderosa pine were significantly shorter than rows containing combinations of ponderosa pine and eastern redcedar. The latter were significantly shorter than rows containing Scots pine and eastern redcedar, all eastern redcedar, or all Scots pine (fig. 2).

At age 12, the following treatments within each species combination row appear to be best in terms of overall development - including foliage density - and should offer the most promise for sustained desirability:

a. Ponderosa pine planted at 4-foot spacing (fig. 3a);

b. Ponderosa pine-eastern redcedar at 6-foot spacing (fig. 3b);

c. Scots pine at 6-foot spacing (fig. 3c);

d. Scots pine-eastern redcedar at 8-foot spacing (fig. 3d);

e. Eastern redcedar at either 4- or 6-foot spacing (fig. 3e).

\section{Discussion and Interpretation}

\section{Fertilization}

Several explanations for the lack of response to fertilization in this study seem plausible. Soil tests revealed no serious nutrient deficiencies. Thus, past fertilization practices on this longcropped field could have created an adequately fertilized soil throughout all treatment plots. The rate of fertilizer applied was not high and was applied only once. Thus response, if any, was not great enough to be detectable. The trees were planted on sandy, upland, nonirrigated land receiving an average annual rainfall of only 24 inches $(600 \mathrm{~mm})$. The fertilizer may not have been fully available to the trees. Perhaps most important, commercial fertilizers applied annually throughout the study period to the field crops planted as close to the tree rows as farm machinery would permit possibly masked any effect of the study fertilizer treatment.

\section{Seedling Survival and Replacement}

The slightly lower survival $(95 \%)$ recorded at the 4- and 8-foot spacings in the ponderosa pineeastern redcedar row, and at the 4-foot spacing in the Scots pine row $(96 \%)$ were attributed to pocket gophers that colonized small segments of the field these rows passed through.
Much of the $8 \%$ total replacement occurred during the first growing season because of drought, and subsequently because of repeated gopher disturbance at the same seedling locations (fig. 1).

\section{Spacing}

At age 12 , trees were starting to compete for space and possibly for soil moisture at a spacing of 4 feet, and to a lesser extent at 6 and 8 feet. Crowns of all species had closed at the 4 -foot spacing by about age 10 and lateral branches were becoming intertwined. This condition was especially noticeable in eastern redcedar (fig. 4). Trees at the closer spacings in all rows were tending to "stretch upward", much the same as closely spaced greenhouse plants which grow taller and spindlier than widely spaced plants. At progressively closer spacings this condition will become more accentuated with time unless the windbreaks are thinned.

\section{Species Combinations (Height)}

Failure of ponderosa pine trees to grow as tall as either eastern redcedar or Scots pine trees was attributed primarily to repeated attacks by the western pine tip moth (Rhyacionia bushnelli) (fig. 5a). Effective control over a 2-year period was obtained on a sample of these study trees by an early spring application of the systemic insecticide phorate (Thimet 15G) (Van Haverbeke et al. 1971). This chemical, however, is not approved for general application to trees.

Eastern redcedar was free of serious insect pests or diseases. Scots pine, while tallest of the three species tested, would have been even taller except for damage by the Zimmerman pine moth (Dioryctria zimmermani). Borings into the central stem at nodes by this insect caused large segments of tops to break off. Eleven percent of all Scots pine trees were severely damaged (fig. 5b).

\section{Species Combinations (Density)}

Tree height and foliage density are important criteria for windbreak efficiency. These results demonstrate that maximum height and density, over the shortest period, are produced at close spacings. To maintain growth and vigor, however, thinnings will usually be required.

The initial 4-foot spacing in ponderosa pine produced the earliest crown closure and the best height growth within 10 to 12 years (left half of fig. 3a). Trees at this close spacing should remain 

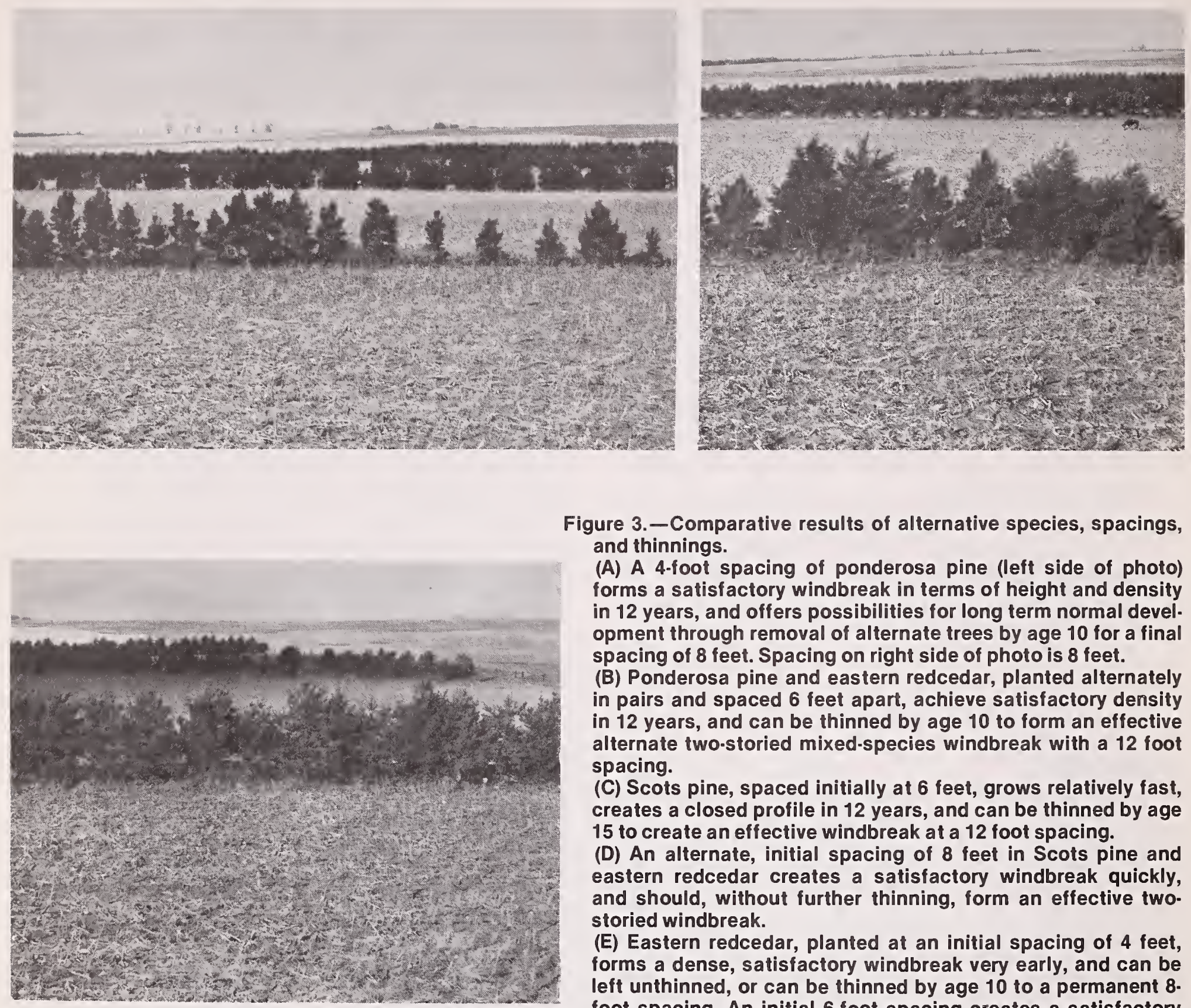

Figure 3.-Comparative results of alternative species, spacings, and thinnings.

(A) A 4-foot spacing of ponderosa pine (left side of photo) forms a satisfactory windbreak in terms of height and density in 12 years, and offers possibilities for long term normal development through removal of alternate trees by age 10 for a final spacing of 8 feet. Spacing on right side of photo is 8 feet.

(B) Ponderosa pine and eastern redcedar, planted alternately in pairs and spaced 6 feet apart, achieve satisfactory density in 12 years, and can be thinned by age 10 to form an effective alternate two-storied mixed-species windbreak with a 12 foot spacing.

(C) Scots pine, spaced initially at 6 feet, grows relatively fast, creates a closed profile in 12 years, and can be thinned by age 15 to create an effective windbreak at a 12 foot spacing.

(D) An alternate, initial spacing of 8 feet in Scots pine and eastern redcedar creates a satisfactory windbreak quickly, and should, without further thinning, form an effective twostoried windbreak.

(E) Eastern redcedar, planted at an initial spacing of 4 feet, forms a dense, satisfactory windbreak very early, and can be left unthinned, or can be thinned by age 10 to a permanent 8 foot spacing. An initial 6-foot spacing creates a satisfactory windbreak in less than 10 years also and should continue to be effective without thinning.
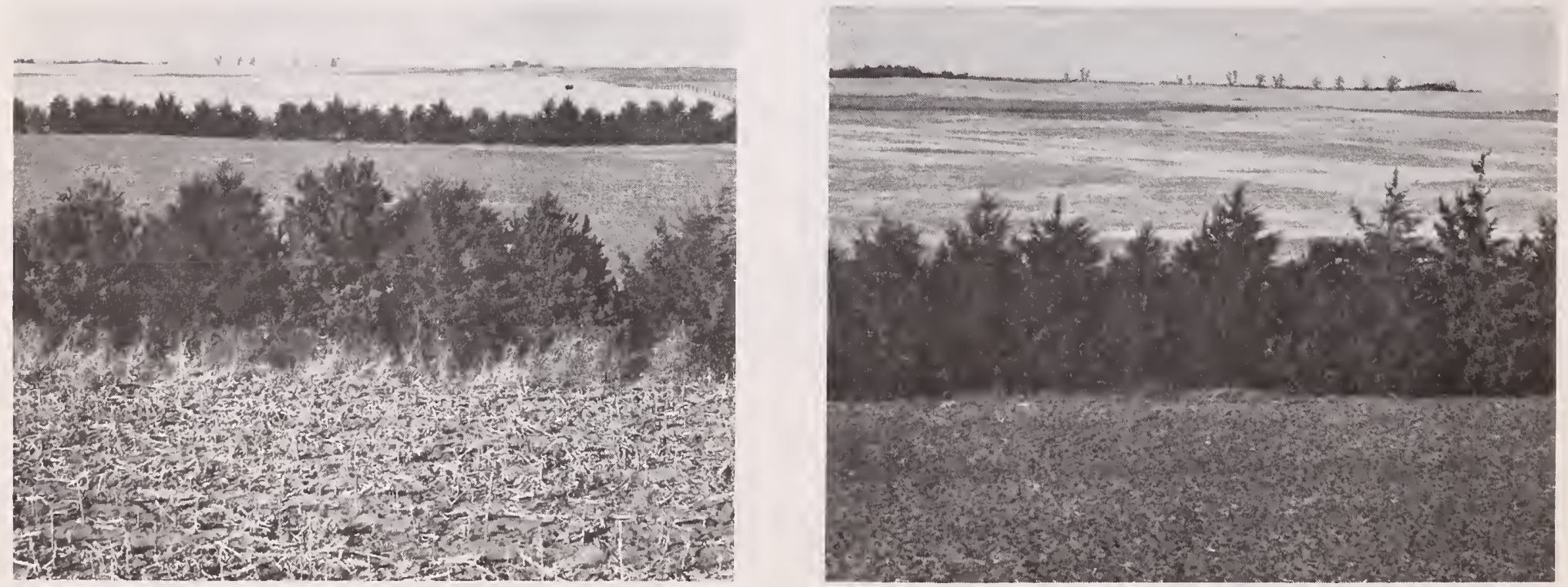


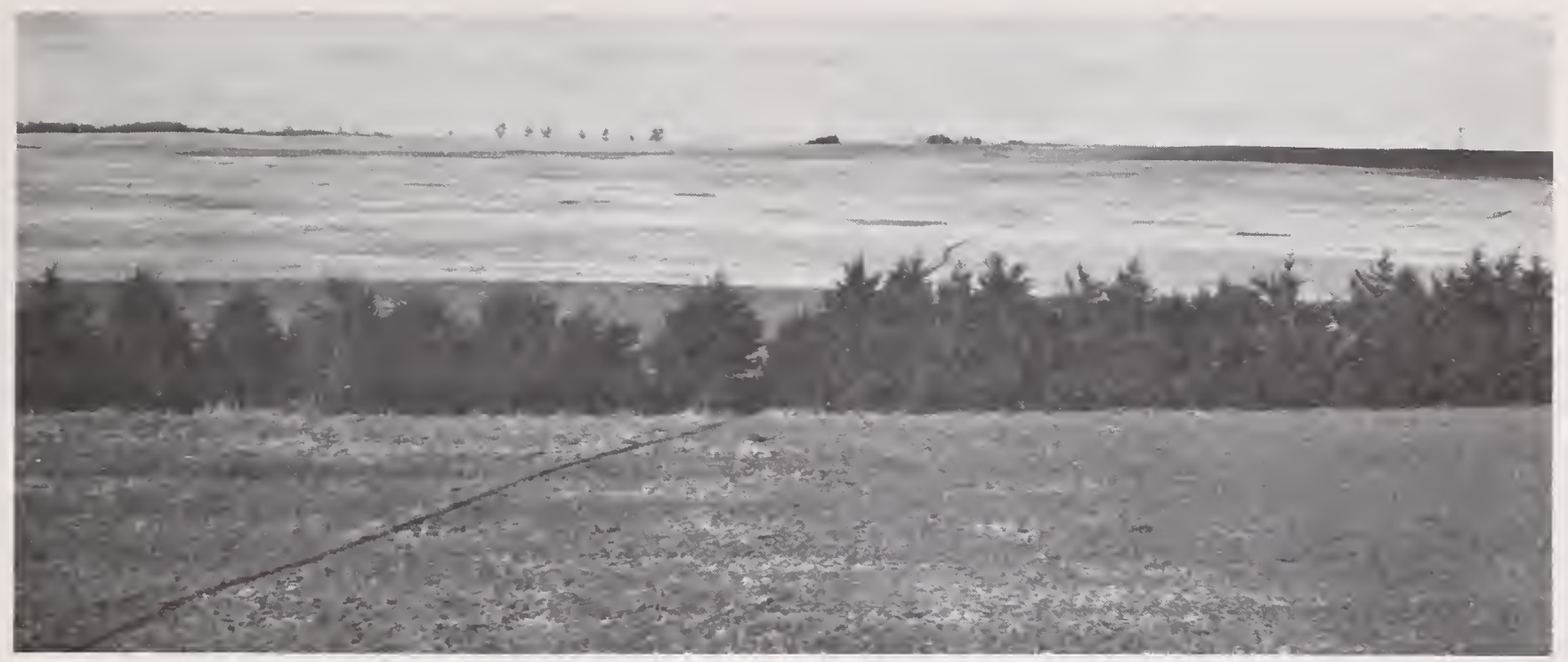

Figure 4.-Lateral branches at the 4-foot spacing (right side of photo) in all species were closed and the trees were becoming competitive for space, and possibly for moisture, after 12 years in all rows, particularly in eastern redcedar. Spacing on left side of phicto is 8 feet.

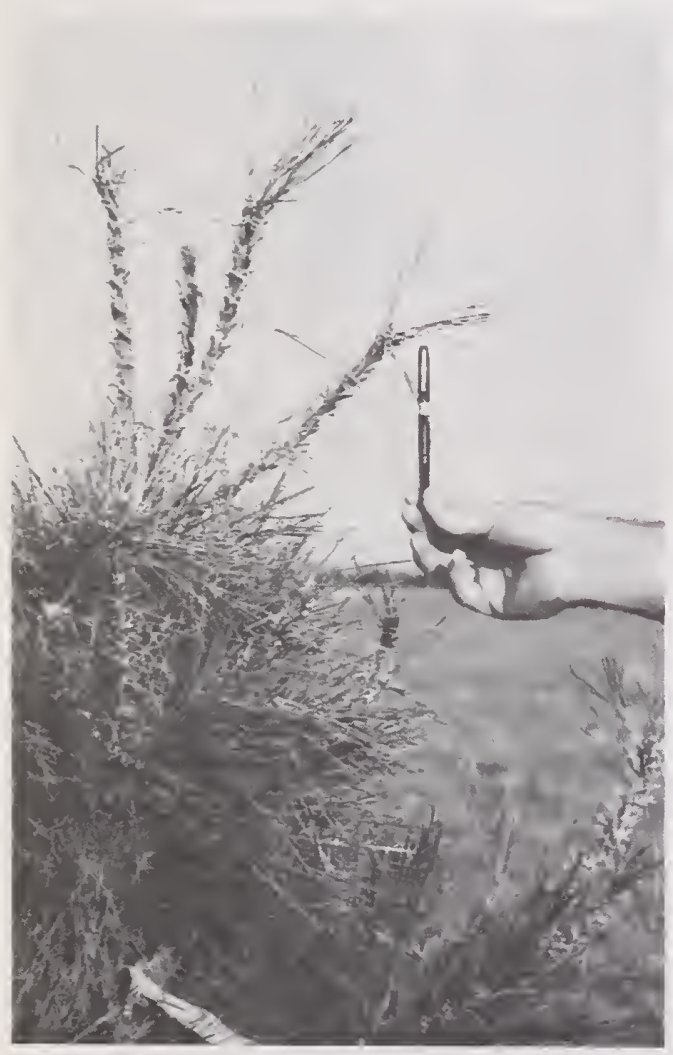

Figure 5.-Susceptibility of individual species to insect attack. (A) Ponderosa pine trees suffered repeated attacks to terminal buds and lateral branches by the western tip moth. Unless control meas. ures are affected, ponderosa pine cannot compete successfully with either Scots pine or eastern red. cedar as a windbreak conifer in this locality.

(B) Eleven percent of all Scots pine trees in this study suffered loss of large segments of their tops from attack by the Zimmerman pine moth.

vigorous up to about 15 years. When crowding becomes apparent, thinning will be necessary to maintain long-term effectiveness. Removal of alternate trees will create a satisfactory windbreak at a permanent 8 -foot spacing. An initial spacing of 8 feet for ponderosa pine would, in time, result in an equally effective windbreak without additional thinning, but would require a long time for. satisfactory crown closure (right half of fig. 3a). The 6-foot spacing will require a fairly long time to achieve effective density; and it will also probably require thinning to provide adequate final growing space. It is also doubtful whether

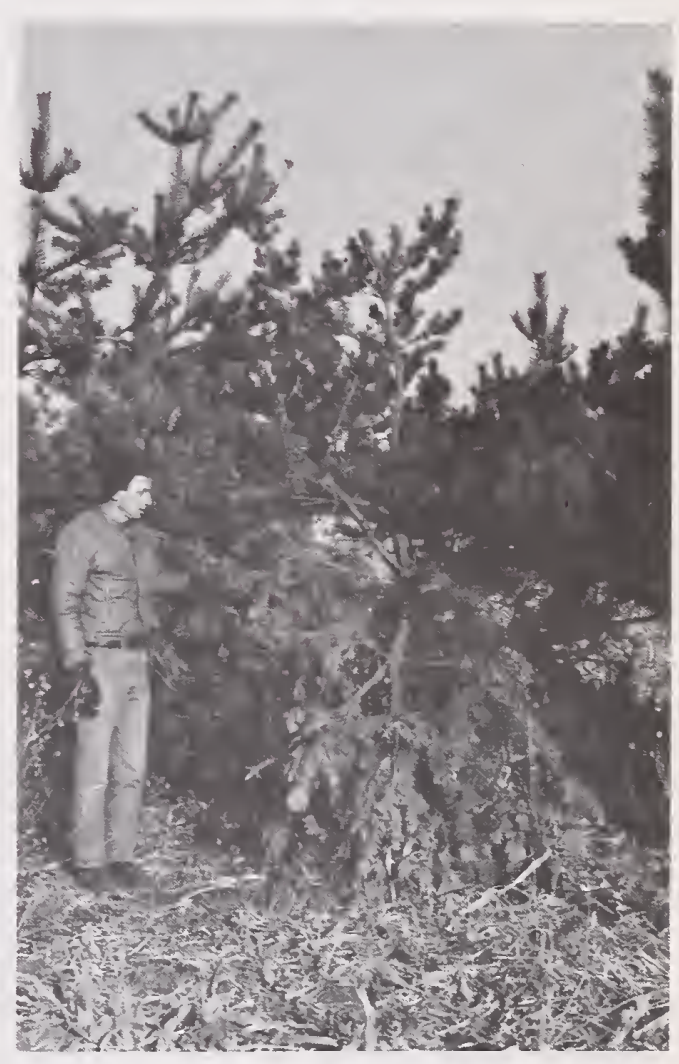

thinning the 6 -foot spacing to a 12 -foot spacing is practical - requiring too many years to achieve effectiveness.

Ponderosa pine and eastern redcedar, planted alternately in pairs at the 6-foot spacing, achieved satisfactory density in 10 years or less because of the rapid lateral growth of eastern redcedar (fig. 3b). Up to age 10 or more, there was little, if any, early suppression of the pine by cedar, as there was at the 4 -foot spacing. Removal of alternate pine and cedar trees at the 6foot spacing should create an effective twostoried windbreak with a 12 -foot spacing. This ar- 
rangement should ultimately produce a windbreak with satisfactory lower level density from the cedar and adequate upper level density from ponderosa pine even though trees of the same species would be spaced 24 feet apart. The initial 8 -foot spacing treatment of alternate pine and cedar promises to eventually make a very satisfactory windbreak, but will require a longer time to become effective because of the relatively slow growth of ponderosa pine.

In Scots pine, an initial spacing of 6 feet produced a satisfactory barrier within 12 years (fig. $3 c)$, and should remain effective at that spacing for about 15 years. Thinning to a spacing of 12 feet by age 15 should create an efficient permanent windbreak with adequate growing space. Scots pine grows relatively fast, and an initial spacing of 4 feet leads to a very early crown closure, but thinning to an 8-foot spacing would probably not provide adequate growing space over a long period of time. An initial spacing of 8 feet requires too much time for crown closure, and again, a long time for crown closure at a spacing of 16 feet $(4.9 \mathrm{~m})$ after thinning.

Scots pine and eastern redcedar planted alternately at 8 feet gives quick crown closure, and without further thinning, should form an effec-

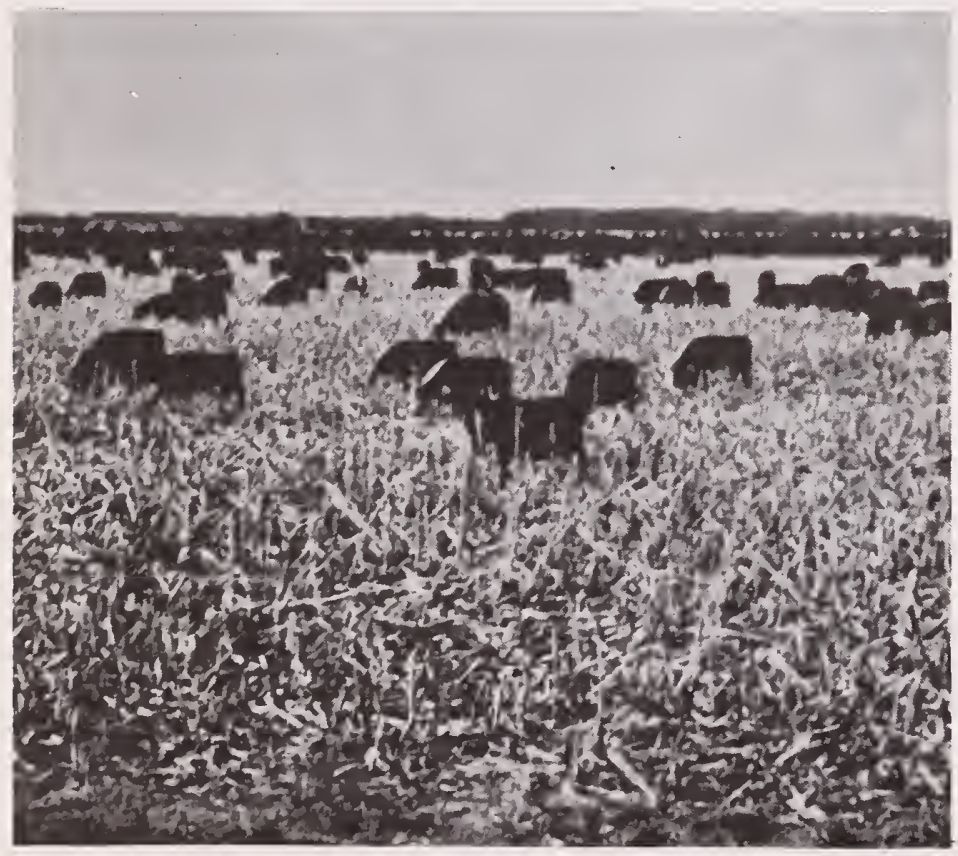

Figure 6. - Landowners commonly turn livestock into their tree-protected fields in late fall until midwinter to glean grain left after harvest. tive two-storied windbreak with lower-story trees (cedar) and upper-story trees (pine) spaced 16 feet apart (fig. 3d). Closer initial spacing of these relatively fast-growing species in the same row would result in crowding and suppression of one or both species.

Eastern redcedar, planted at a spacing of 6 feet, closes in 10 years or less, and could be left unthinned for a very dense permanent windbreak. A 4 -foot spacing resulted in a closed profile very early; and could also be left unthinned with perhaps some sacrifice of tree vigor over a long period of time (fig. 3e).

\section{Livestock Damage}

It is widely recognized that trees and livestock are not compatible (Ferrell 1956, Read 1957). Landowners, however, turn livestock into their fields from late fall until midwinter to glean the fields of grain left after harvest. This has been the situation during the past several years on the present study site after the Allemang's changed from continual rye to a rye-corn rotation (fig. 6). As a result, some damage to unprotected trees is apparent. Figure 7 depicts the worst of the live-

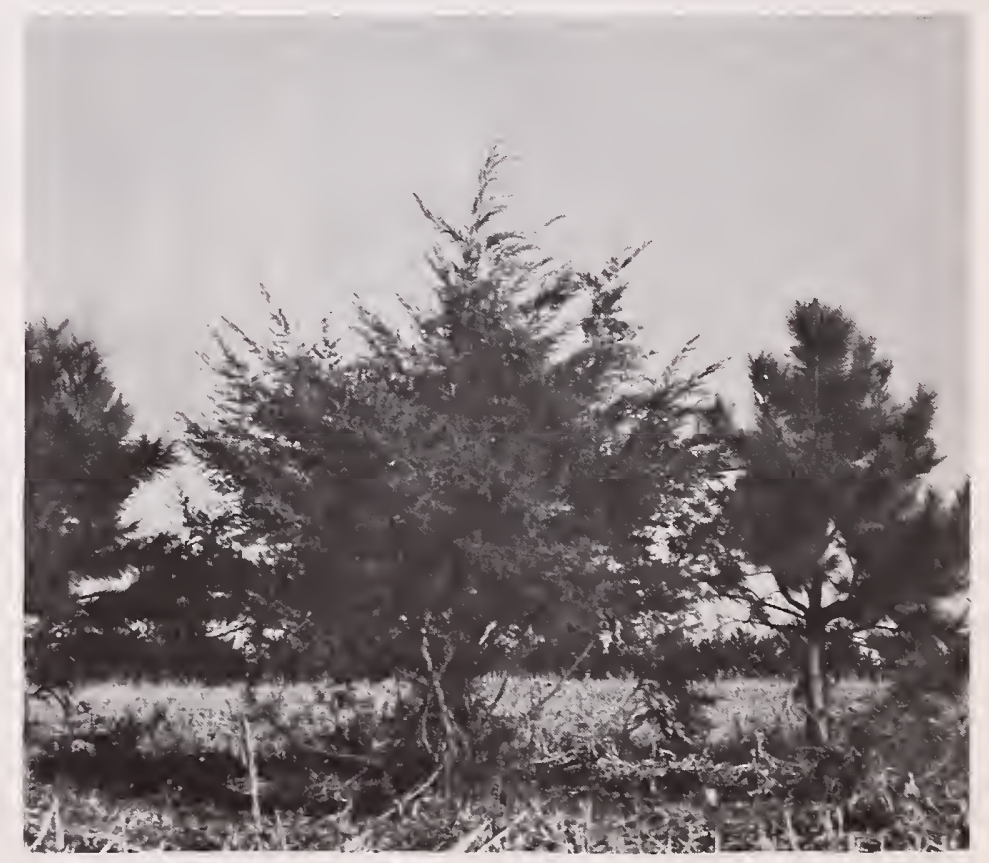

Figure 7.-Damage to unfenced single-row windbreaks is inevitable and will increase each season of livestock oc. cupancy. 
stock damage to these windbreaks. We can expect further damage to these windbreaks, however, with each additional season of livestock occupancy; and this damage will be accumulative. We appreciate that fencing single-row windbreaks is restrictive to livestock movement within the field, is expensive, and is generally considered impractical. It is, however, the only satisfactory solution to the age-old "trees vs. livestock" dilemma. Temporary single-strand electric fences would seem to offer a workable solution; but the answer to this problem will depend upon the priorities and concern of the individual landowners.

\section{Literature Cited}

Bagley, Walter T. 1962. Tree response to fertilizer applied at planting. J. Soil and Water Conserv. 17(3):117-119.

Bates, C. G. 1944. The windbreak as a farm asset. U.S. Dep. Agric. Farmers' Bull. 1405 (rev.), $22 \mathrm{p}$.

Caborn, J. M. 1965. Shelterbelts and windbreaks. 288 p. Faber and Faber Ltd., London.

Cram, W. H., and G. A. Morgan. 1961. Survival and growth of shelterbelt trees at three spacings. For. Chron. 37(3):187-191.

Deters, M. E., and Henry Schmitz. 1936. Drought damage to prairie shelterbelts in Minnesota. Minn. Agric. Exp. Stn. Bull. 329, 28 p.

Dickerson, J. D., and N. P. Woodruff. 1969. Tree shrubs and annual crops for wind barriers in central and western Kansas: An interim report on growth, survival and shelter effect. Agric. Exp. Stn., Kans. State Univ., Tech. Bull. 153, $29 \mathrm{p}$.

Eaton, H. J. 1971. Shelterbelts and hedges. Agriculture (London) 78, 5:185-189.

Emerson, J. L. 1940. Spacing standards. Plains For. 5(3):1-4.

Ferrell, E. K. 1956. Grazing ruins shelterbelts. S. Dak. Agric. Ext. Serv. Leafl. 176.

Ferrell, E. K. 1957. Shelterbelts for South Dakota. S. Dak. State Coll. U.S. Dep. Agric. Ext. Serv. Circ. 492 (rev.), 24 p.

George, E. J. 1936. Growth and survival of deciduous trees in shelterbelt experiments at Mandan, N. Dakota 1915-1934. U.S. Dep. Agric. Tech. Bull. 496, 48 p.

George, E. J. 1948. Spacing distances for windbreak trees on the northern Great Plains. U.S. Dep. Agric. Circ. 770, 28 p.

George, E. J. 1953a. Tree and shrub species for the northern Great Plains. U.S. Dep. Agric. Circ. 912, 46 p.
George, E. J. 1953b. 31-year results in growing shelterbelts on the northern Great Plains. U.S. Dep. Agric. Circ. 924, 57 p.

Greb, B. W., and A. L. Black. 1961. Effects of windbreak plantings on adjacent crops. J. Soil and Water Conserv. 16(5):223-227.

Hansen, N. E. 1930. Evergreens in South Dakota. S. Dak. Agric. Exp. Stn. Bull. 254, 33 p.

Isaac, E. E. 1941. Planting and care of shelterbelt trees. Mont. Agric. Coll. Ext. Serv. Circ. 112, $4 \mathrm{p}$.

King, E. 1970. Ecological and meteorological studies on shelterbelts in the wet summer of 1968. Agric. Meteor. 7(3):235-253 [in German].

Nagle, J. P., and E. H. Steffen. 1953. Growth rates of trees in farm windbreaks. Wash. Agric. Exp. Stn. Circ. 222, 4 p.

Podkopaev, A. A. 1975. The creation of agronomically effective shelterbelts in the southern Chernozem zone of the Ukraine. Forest. Abstr. 36(4), No. 2053, p. 186.

Randel, G. L. 1959. Coniferous windbreak species and spacing tests at the Big Spring Field Station. Texas Agric. Exp. Stn. Misc. Publ. 360. $2 \mathrm{p}$.

Read, Ralph A. 1957. Effect of livestock concentration on surface-soil porosity within shelterbelts. J. For. 55(7):529-530.

Read, Ralph A. 1964. Tree windbreaks for the central Great Plains. U.S. Dep. Agric. Handbk. No. 250,68 p.

Rockwell, F. I. 1943. Planting windbreaks to survive drought in South Dakota. S. Dak. Agric. Coll. Ext. Circ. 397, 7 p.

Ross, N. M. 1939. Tree-planting on the prairies of Manitoba, Saskatchewan and Alberta, Canada. Dep. Agric. Publ. 623, Farmers' Bull. 64,62 p.

Siddoway, F. H. 1970. Barriers for wind erosion control and water conservation. J. Soil and Water Conserv. 25(5):180-184.

Smith, M. E. 1961. Windproof your farm with one-row windbreaks. Minn. Univ. Ext. Serv. Folder 217, 6 p.

Stoeckeler, Joseph H. 1963. Shelterbelts and their effects on crop yields in the Great Plains. J. Soil and Water Conserv. 18(4):139-144.

Sturrock, J. W. 1972. Aerodynamic studies in shelterbelts in New Zealand: 2-medium height to tall shelterbelts in mid Canterbury. N. Z. J. Sci. 15(2):113-140.

Sturrock, J. W. 1975. The control of wind in crop production. p. 349-462. In Progress in Biometeorology. Vol. 1. L. P. Smith, Ed.

Van Eimern, J. R., R. Karschon, L. A. Razumova, and G. W. Robertson. 1964. Windbreaks and shelterbelts. World Meteorol. Organ., Tech. Note 59, $188 \mathrm{p}$. 
Van Haverbeke, David F., Robert E. Roselle, and Gary D. Sexson. 1971. Western pine tip moth reduced in ponderosa pine shelterbelts by systemic insecticides. USDA For. Serv. Res. Note RM-194, 8 p.

Ware, E. R. 1936. Planting and care of trees in South Dakota. S. Dak. State Coll. Ext. Circ. $356,56 \mathrm{p}$.

Woodruff, N. P., D. W. Fryrear, and L. Lyles. 1963. Reducing wind velocity with field shelterbelts. Kans. State Univ. Agric. Exp. Stn. Tech. Bull. 131, 26 p.
Woodruff, N. P., J. D. Dickerson, E. E. Banbury, A. B. Erhart, and M. C. Lundquist. 1976. Selected trees and shrubs evaluated for singlerow windbreaks in the central Great Plains. USDA, Agr. Res. Serv., ARS-NC-37, 15 p.

Worthington, Elmer L. 1960. From "dust bowl" to "tree bowl". Am. For. 66(6):11-13, 46-47.

Yeager, A. F. 1921. Shelterbelts for North Dakota. N. Dak. Agric. Coll. Ext. Circ. 43, 7 p.

Zalyskie, J. J., and E. L. Worthington. 1962. Wrap your fields in windbreaks. N. Dak. State Univ. Ext. Serv. Circ. A-377, 4 p.

The use of trade and company names is for the benefit of the reader; such use does not constitute an official endorsement or approval of any service or product by the U.S. Department of Agriculture to the exclusion of others that may be suitable. 


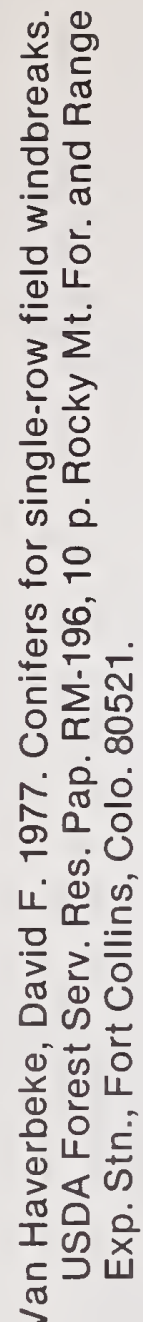

广்

๙

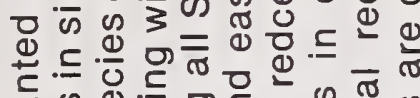

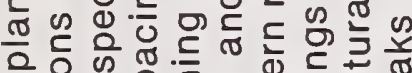

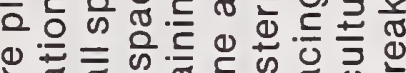

ब

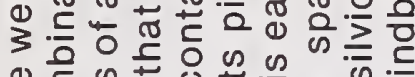

Q E \&

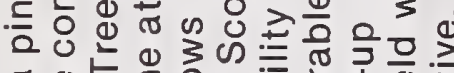

ช

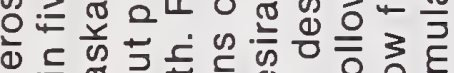

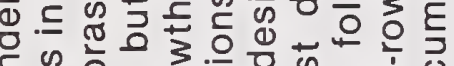

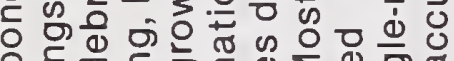

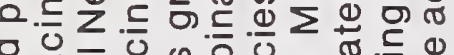

六

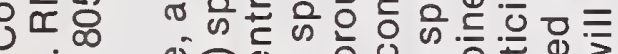

Фิ)

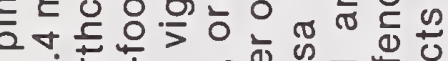

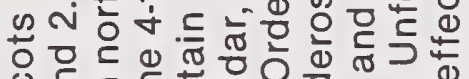

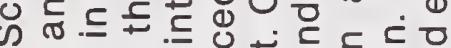

-

สำ

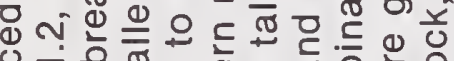

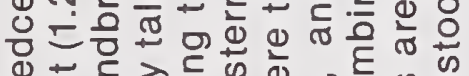

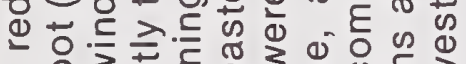

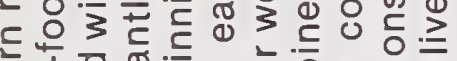

๘

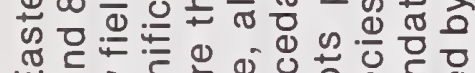
ம่



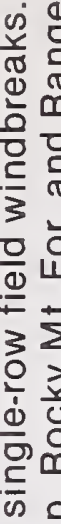

흐으

๑ั

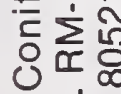

กิํํㅇำ

둥

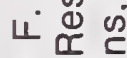

을 $\geq$

更

ब出要

인

운

$\gg \frac{10}{0}$

王官这

든
ச்

त

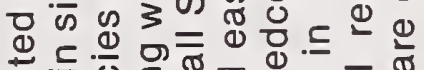

드워

뜽 ๑ั

d

光.

क है

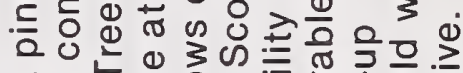

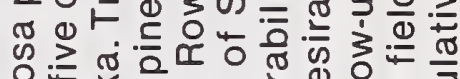

은

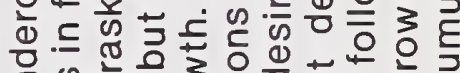

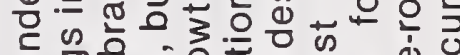

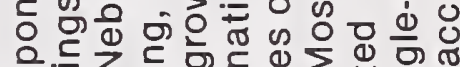

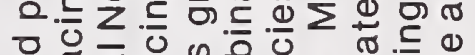

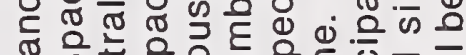

का की

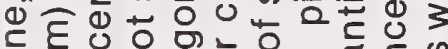

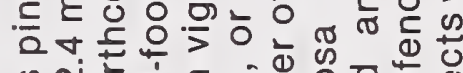

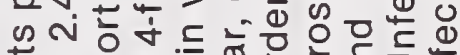

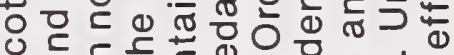

ஸั

$\sim \infty$ 후

สัต

ฮำ

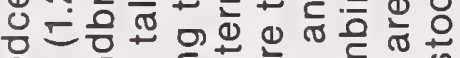

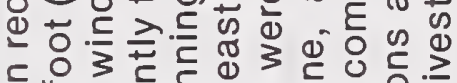

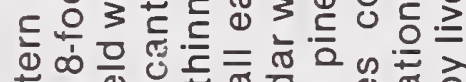

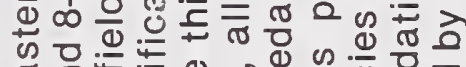

政

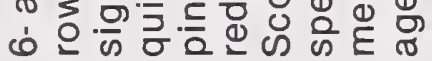

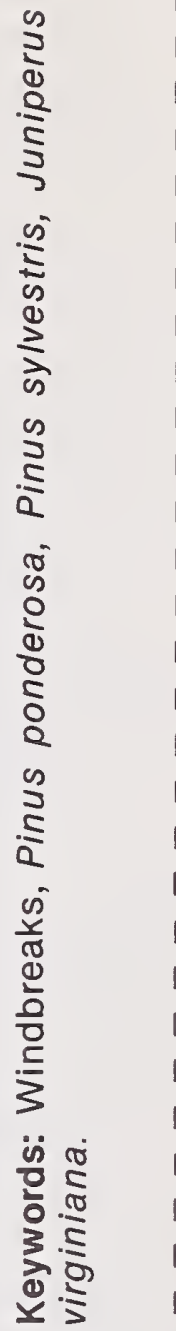

ம்

光

บั

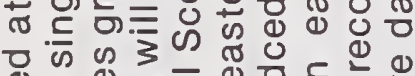

음음

क

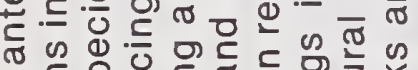

ऊ

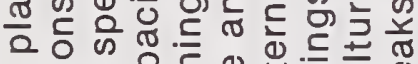

응누

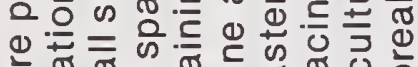

$3 \stackrel{+}{\Sigma}$

잉

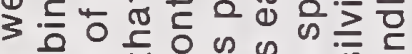

은 종

ब है

ఏ่

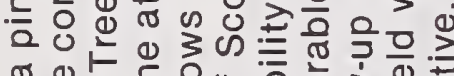

무

ส

क⿺

는으

은

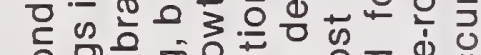

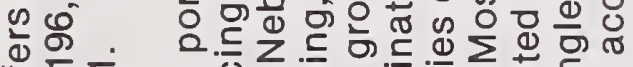

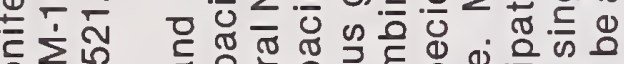

ठำ

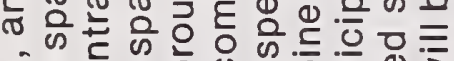

용ㅇ

बं हे

कूष

ए.

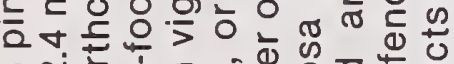

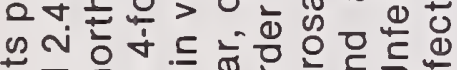

을

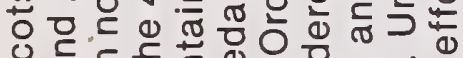

đั

ब古范

닌

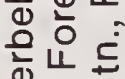

以

-

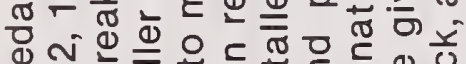

응 능

ब

$D^{2}$ क

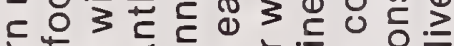

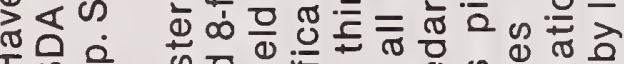

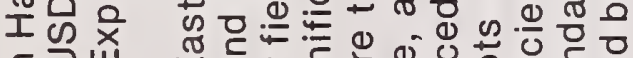
ᄃ

่

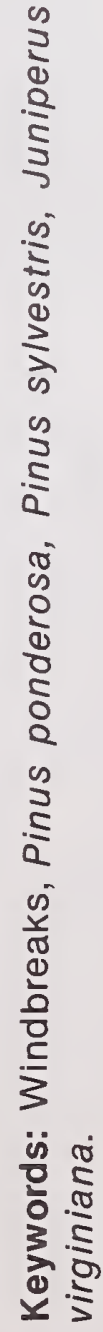

के

次

뜬

믇읃

年

흔 우

要

$3 \sum$

잉

임엄

क⿺

흔으

๘)

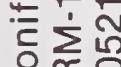

نㄸ

ㄷำำ

可识

นن $\stackrel{\infty}{\mathscr{Q}}$

ㄴ.

을

更过

बi

诸

은

क⿺辶万人

王宽

ᄃ

>
ச்

元. 万人.

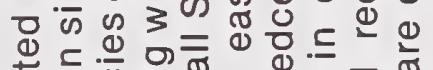

드워

สำ

응 응등

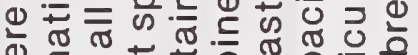

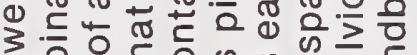

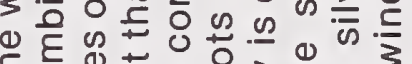

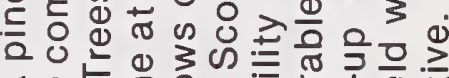

『

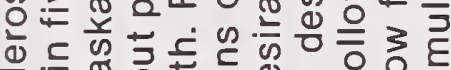

응

은

웡

๙ की क⿺ 一兀

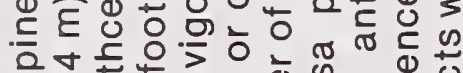

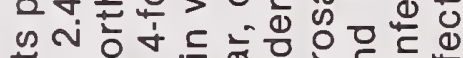

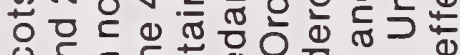

ஸ

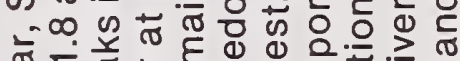

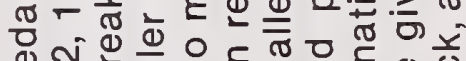

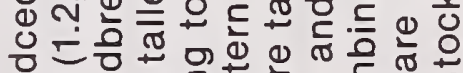

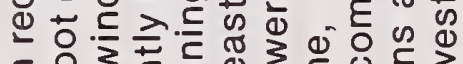

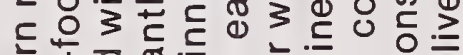

ఖ

क

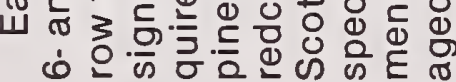




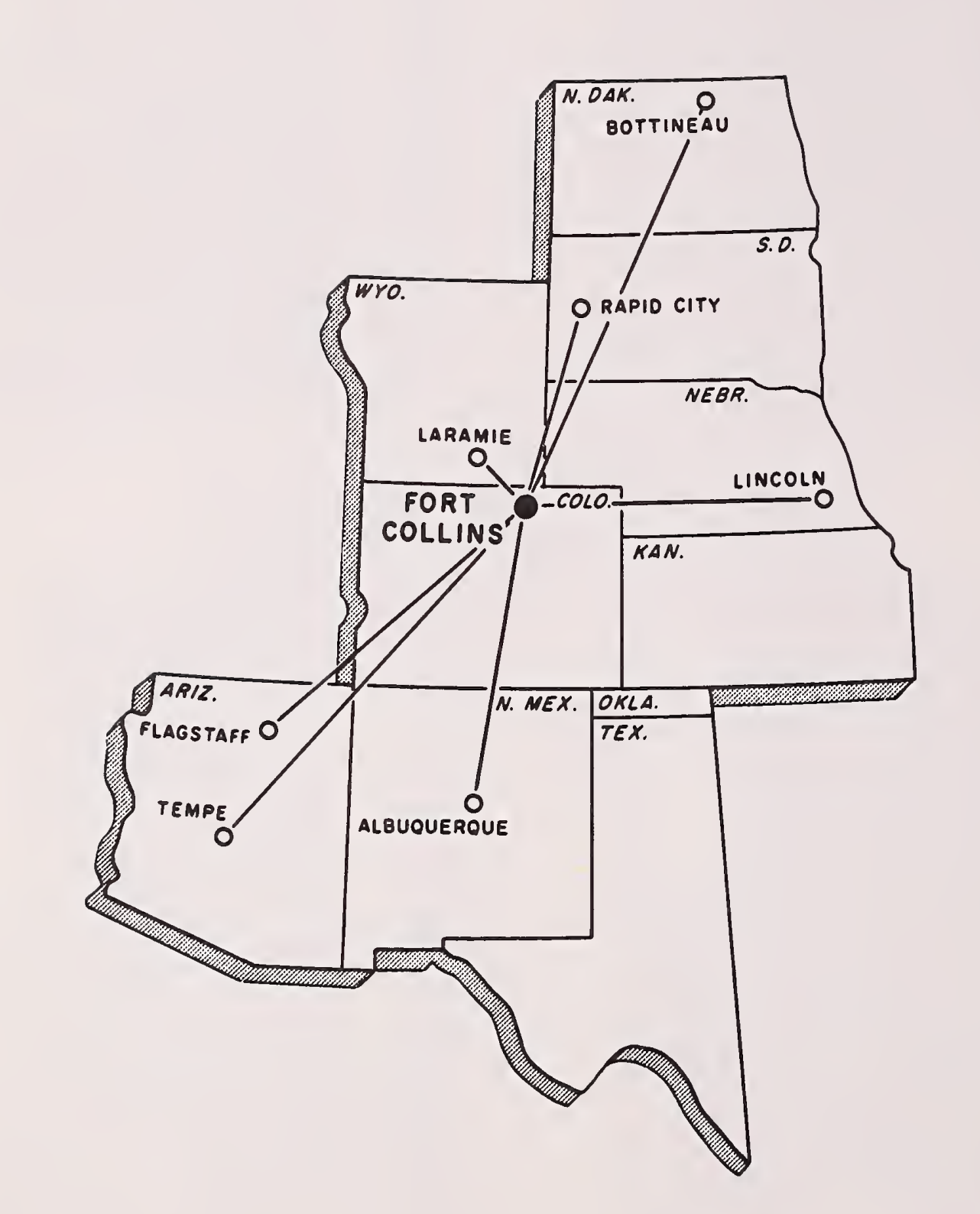

